\title{
Effects of an experimental reduction in grazing by green sea urchins on a benthic macroalgal community in eastern Newfoundland*
}

\author{
Derek W. Keats ${ }^{1}$, G. Robin South ${ }^{2}$, D. H. Steele ${ }^{3}$ \\ ${ }^{1}$ Botany Department, University of the Western Cape, Private Bag X17, Bellville 7535, South Africa \\ ${ }^{2}$ Institute of Marine Resources, University of the South Pacific, Suva, Fiji \\ ${ }^{3}$ Department of Biology, Memorial University of Newfoundland, St. John's, Newfoundland, Canada A1B 3X9
}

\begin{abstract}
An urchin removal experiment was performed over $5 \mathrm{yr}$ at a heavily grazed, sublittoral site in Conception Bay, Newfoundland. Three transects were used: one unmanipulated, one from which urchins were removed manually for $3 \mathrm{yr}$, and one from which urchins were removed using quicklime. Each site was sampled in the upper ( 2 to $3 \mathrm{~m}$ ) and middle ( 6 to $9 \mathrm{~m}$ ) urchin-dominated zone. Macroalgal biomass increased following urchin removal by both methods. At 2 to $3 \mathrm{~m}$ a closed canopy of Alaria esculenta developed,with few other algal species, except during the summer when the canopy was reduced by blade erosion. The community that developed at 6 to $9 \mathrm{~m}$ consisted mainly of Desmarestia aculeata, with lesser amounts of other canopy-forming algae (A. esculenta, Agarum cribrosum, and Laminaria digitata). When urchins were allowed access to the urchin removal sites, they grazed away all algae except A. cribrosum and Ptilota serrata. Some A. cribrosum survived for at least 2 yr after urchin reinvasion. Algal biomass in the unmanipulated area was low for the first $3 \mathrm{yr}$, but both biomass and species richness increased during the summers of 1982 and 1983. These algae were removed by urchin grazing and natural senescence during the autumn and winter. The species composition of this temporary summer community differed, however, from the community on the removal transects, and was dominated by annual algae such as Acrothrix novae-angliae, Chordaria flagelliformis, Dictyosiphon foeniculaceus, Ectocarpus siliculosus, and Eudesme virescens, whereas perennials such as $A$. esculenta and $D$. aculeata dominated in the urchin removal area.
\end{abstract}

\section{INTRODUCTION}

Extensive rocky subtidal areas, which are devoid of large fleshy macrophytes as a result of grazing by the green sea urchin Strongylocentrotus droebachiensis, occur from Massachusetts, USA, to Labrador, Canada (Breen \& Mann 1976, Mann 1977, Hooper 1980, Chapman 1981, Harris 1981, Himmelman et. al. 1983, Himmelman 1985, Keats pers. obs. 1977-1989). Areas dominated by green sea urchins have also been reported in the Northeast Atlantic (Hagen 1983), on the Barents Sea coast of the Soviet Union (Propp 1977), and in various localities in the Northeast Pacific (Vadas 1968, Foreman 1977). Such urchin-dominated communities have been referred to as 'barrens' (Lawrence

- Newfoundland Institute for Cold Ocean Science Contribution No. 95
1975), but the terms 'heavily grazed bottom' and 'sea urchin dominated communities' are used here. The removal of urchins from such areas, either artificially or naturally, generally leads to the recovery of abundant canopy-forming macrophytes (Jones \& Kain 1967, Lawrence 1975, Breen \& Mann 1976, Pearse \& Hines 1979, Duggins 1980, Chapman 1981, Himmelman et al. 1983, Miller 1985, Harrold \& Pearse 1987).

Several studies on heavily grazed bottom in the Northwest Atlantic have revealed differences among areas in terms of the history of sea urchin grazing, and of the detailed response of the algal community to reductions in urchin grazing. For example, the outbreak of urchins which occurred in Nova Scotia (near the southern limit of the species' range) during the early 1970 's, and which was terminated by an amoebacaused disease in the early 1980 's, has had no counterpart in the colder part of the Northwest Atlantic (Breen 
\& Mann 1976, Mann 1977, Himmelman 1980, 1985, Chapman 1981, Himmelman et al. 1983, Moore \& Miller 1983, Scheibling 1984, 1986, Jones et al. 1985 , Miller 1985, Keats 1986, Pringle 1986, Hart \& Scheibling 1988). Therefore, studies from outside the area subjected to these alternations between urchins and kelp will make worthwhile contributions to our understanding of the role of grazing by green sea urchins on a broader geographical scale.

The approach taken here is to use the well-established technique of urchin removal to examine the response of benthic algal community structure to a reduction in urchin grazing pressure at an urchin dominated site under the direct influence of the cold Labrador Current. Aspects of community structure include species composition, species diversity, the relative abundances of species, the spatial and temporal patterns of species abundances, and morphological characters of the dominant species (Tilman 1982). We have examined changes in these community characteristics, for the algal component of the community, in relation to the experimental reduction in sea urchin grazing.

\section{MATERIALS AND METHODS}

Study area. Three subtidal transects were utilized (Fig. 1); one left unmanipulated, one from which urchins were removed manually, and one from which urchins were removed by quicklime application. The study sites were in Conception Bay, the outer portion of which has 3 distinct seaweed zones as is typical of the open Atlantic coast of Newfoundland. These zones are: a shallow zone ( 0 to $2 \mathrm{~m}$ ) with abundant fleshy macrophytes [described by Keats et al. (1985a)]; a heavily grazed zone (2 to $12 \mathrm{~m}$ ) dominated by Strongylocentrotus droebachiensis, with a much reduced abundance of fleshy macroalgae; and a deeper Agarum/Ptilota zone (>12 m) [described by Keats et al. (1982)]. Coralline algae, mainly Clathromorphum circumscriptum, Corallina officinalis, Phymatolithon rugulosum, Phymatolithon laevigatum, and Lithothamnion glaciale, are well developed throughout the study area, and cover 80 to $90 \%$ of the substratum.

Over a 5 yr period detailed analyses were conducted within 2 separate depth ranges corresponding to the upper ( 2 to $3 \mathrm{~m}$ ), and middle (6 to $9 \mathrm{~m}$ ) of the urchindominated zone. The area within which samples were taken was ca $100 \mathrm{~m}^{2}$ at 2 to $3 \mathrm{~m}$ and ca $200 \mathrm{~m}^{2}$ at 6 to $9 \mathrm{~m}$. The substratum consists of bedrock from the intertidal to ca $6 \mathrm{~m}$ depth, and a mixture of bedrock and small densely-packed boulders to ca $25 \mathrm{~m}$ depth.

Manual removal of urchins. At the manual removal site (10 m wide $\times 40 \mathrm{~m}$ offshore) from June to August
1980 urchins were systematically killed using hammers, to a depth of $10 \mathrm{~m}$. Thereafter, urchins were killed every 1 to 2 wk in summer, and ca monthly in winter. Urchins smaller than 10 to $15 \mathrm{~mm}$ test diameter occupy cryptic microhabitats, and hence were not as effectively removed as larger individuals (see Keats et al. 1985b). To reduce sea urchin reinvasion, the manual removal area was surrounded by a $1.5 \mathrm{~m}$ high compound constructed of $3 \mathrm{~cm}$ mesh seine netting, with a $1.5 \mathrm{~m}$ skirt onto which boulders were placed. Urchin removal ceased in September 1983, after which observations were made but no quantitative samples were taken.

Application of quicklime. To provide a larger replicate urchin removal plot, quicklime application was used at another site. A trial application of $0.8 \mathrm{~kg} \mathrm{~m}^{-2}$ quicklime to $100 \mathrm{~m}^{2}$ eliminated a large enough portion of the urchin population to allow macroalgal colonization. Therefore this dosage was used for the experiment. An area $90 \mathrm{~m}$ (parallel to the shore) by $40 \mathrm{~m}$ (perpendicular to the shore), extending to a depth of $15 \mathrm{~m}$ (ca $3800 \mathrm{~m}^{2}$ ) was marked at a sight in Conception Bay (Fig. 1). A total of $2800 \mathrm{~kg}$ of granular high calcium quicklime (Pfizer Chemical, Adams, Mass., USA) was applied using an agricultural seed spreader attached to a boat. Half of this amount was applied on October 22, and the remainder on November 18, 1981. Observations made on December 5 showed that in the southern portion of the area ca $90 \%$ of the substratum received relatively even coverage of quicklime, with the evenness of coverage decreasing considerably toward the northern portion of the area. To prevent the encroachment of urchins into the study area from the area to the north, $2800 \mathrm{~kg}$ of quicklime was applied to another $3500 \mathrm{~m}^{2}$ during June of 1982 . To avoid edge effects subsequent detailed observations and biomass sampling were made within a $40 \mathrm{~m}$ wide section $\left(1700 \mathrm{~m}^{2}\right)$ within the area treated in 1981.

Sampling procedure. Sampling periods (Table 1) were chosen to reflect the seasonal changes in floristics which have been reported for the Newfoundland inshore (Hooper et al. 1980). These were spring (May), summer (July), and autumn (October). Rough sea conditions and lack of adequate diving support reduced the effectiveness of sampling during spring and autumn, and prevented winter sampling.

A $0.1 \mathrm{~m}^{2}$ quadrat was used for sampling because of sorting and measurement logistics. We aimed for a sample size of 10 quadrats per treatment, but because of logistic constraints, actual sample size ranged from 5 to 10 (exceptionally 3 or 4 ). Due to rough sea conditions, quadrats were placed by blind casting at each depth range. A combination of hand-harvesting and air dredging was used.

Variables measured included total macroalgal bio- 


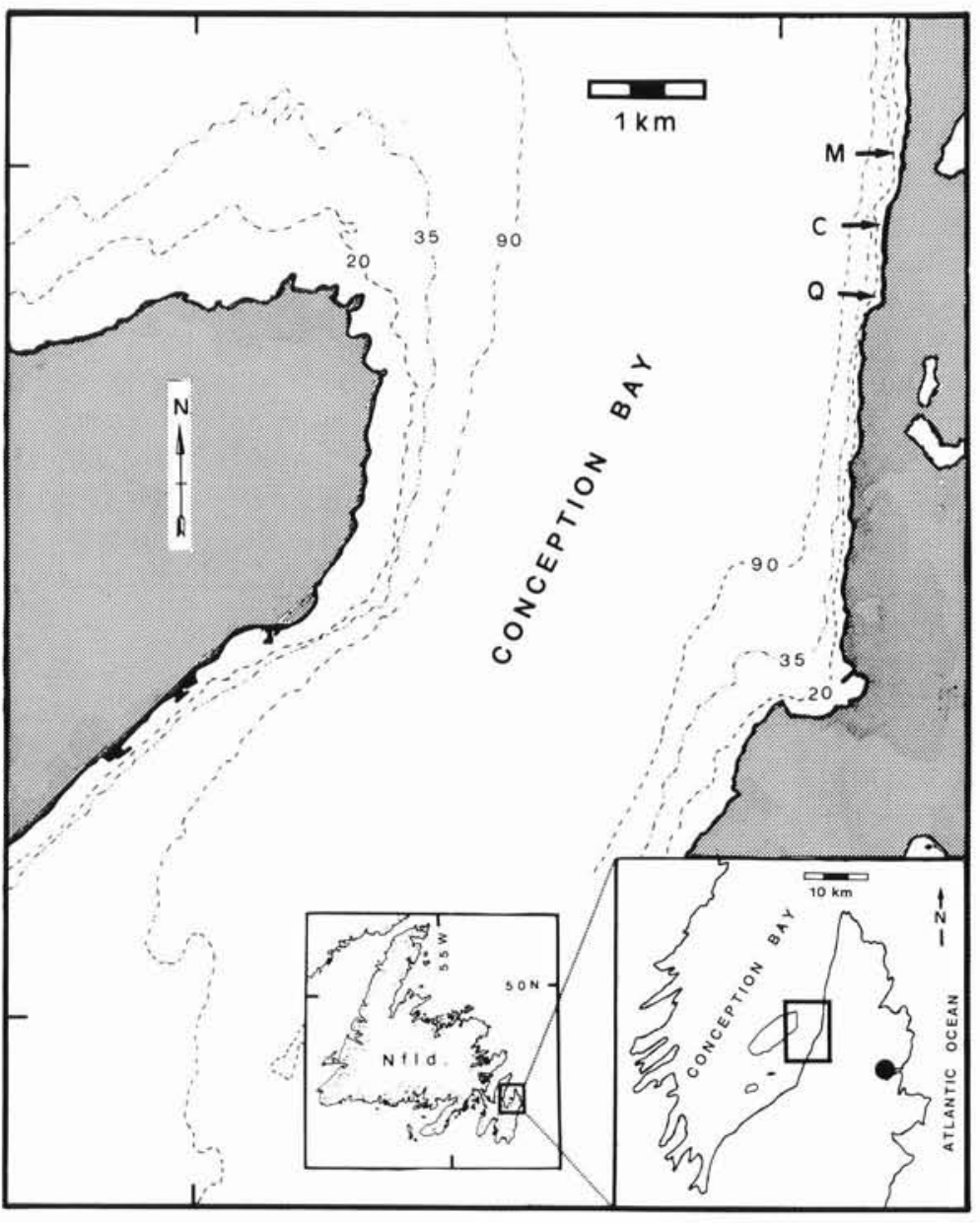

Fig. 1. Location of study areas in Conception Bay Newfoundland. M: manual removal transect; C: unmanipulated transect; Q: quicklimed transect. Dot on inset map is location of St. John's. Depth contours (m) from nautical chart 4566

mass (except for crustose species), and biomass of individual species. Only species which were large enough to observe in the field, or present in large enough quantities to be seen in a sorting tray were included for analysis. Species present, but at a biomass below the resolution of the balance $(0.05 \mathrm{~g})$ were recorded as 'present' (+). Urchin wet weight was also measured, as a means of assessing the effectiveness of their removal.

Laboratory sorting and identification were made on fresh or frozen material. Algae were sorted by species, blotted for ca $5 \mathrm{~min}$ to remove surface water, and wet weighed. In addition to destructive sampling, species counts and general observations were made in the study areas at least monthly. Species counts were made by traversing the study area for $20 \mathrm{~min}$ at each depth range and recording the species present. Uncertain taxa were returned to the laboratory for identification. Observations were continued intermittently for $2 \mathrm{yr}$

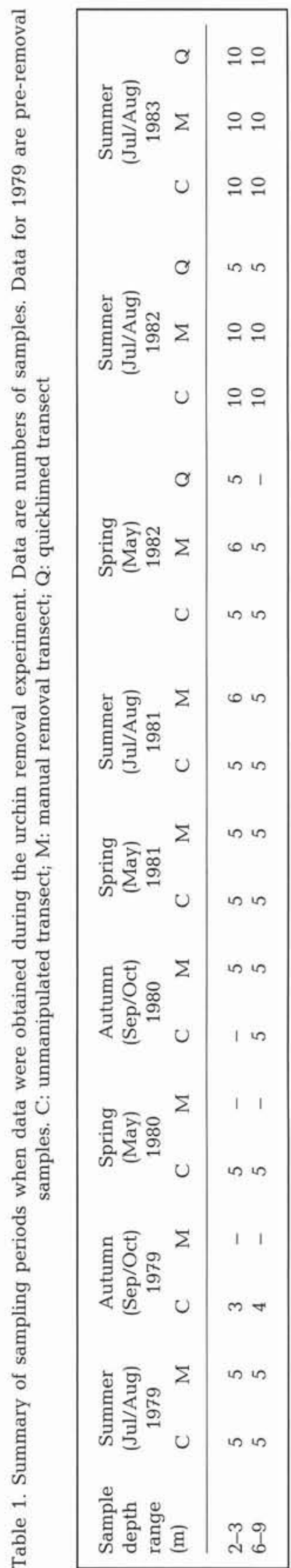


after urchins were allowed access to the manual removal site.

All algal species names and authorities follow South (1984), except Scagelia pylaisaei (Mont.) Wynne (Wynne 1985).

Data analysis. Species richness is used here to represent the totai number of species counted during monthly observations, and species importance curves were obtained as outlined in Whittaker (1965) and May (1981). Such curves provide a ready visual assessment of diversity without the great loss of information inherent in diversity indices. For convenience in the graphical analysis of species-biomass, species were broken down according to canopy (only includes the larger phaeophytes) and non-canopy species (sensu Dayton 1975). Since the latter group showed no clear trends in biomass, these data are not presented graphically (see Keats 1986).

Confidence limits about an estimate of percentage urchin biomass removed are based on the a priori contrasts of 'untreated' (i.e. unmanipulated and pooled pre-removal samples from the manual removal transect) versus 'treated' (i.e. post-removal samples) for each depth range averaged over all sample periods. Geometric means and back-transformed confidence limits were used for these calculations, and for all graphs showing standard errors, because of heteroscedasticity and deviation from normality (Sokal \& Rohlf 1969). Arithmetic means were used for calculation of percent biomass by species, as no statistical tests or related calculations were performed on these data.

\section{RESULTS}

\section{Total biomass of algae}

Before 1981 biomass on the unmanipulated transect was negligible, but it increased at 2 to $3 \mathrm{~m}$ during the summers of 1981 to 1983 , and at 6 to $9 \mathrm{~m}$ during the summers of 1982 to 1983 (Fig. 2). Few algae were observed after October of any year, as almost all were removed by urchin grazing and natural senescence during the late summer and autumn. On both urchin removal transects, macroalgal biomass increased and remained relatively high after urchin removal (Fig. 2). During summer 1982, however, when a major increase in biomass occurred on the unmanipulated transect, biomass was similar on all transects (Fig. 2).

\section{Canopy species}

Alaria esculenta had the greatest biomass at 2 to $3 \mathrm{~m}$ following urchin removal (Fig. 3). A few A. esculenta sporelings appeared in the manual removal area in early December 1980, but peak recruitment was observed during March 1981. By May 1981 the A. esculenta sporophytes had attained a large size, and biomass was high (Fig. 3). Other canopy species, present at low biomass on the manual removal transect during 1981, were largely gone by 1982, after which most biomass was $A$. esculenta. This trend was repeated on the quicklimed transect during 1982 and 1983.

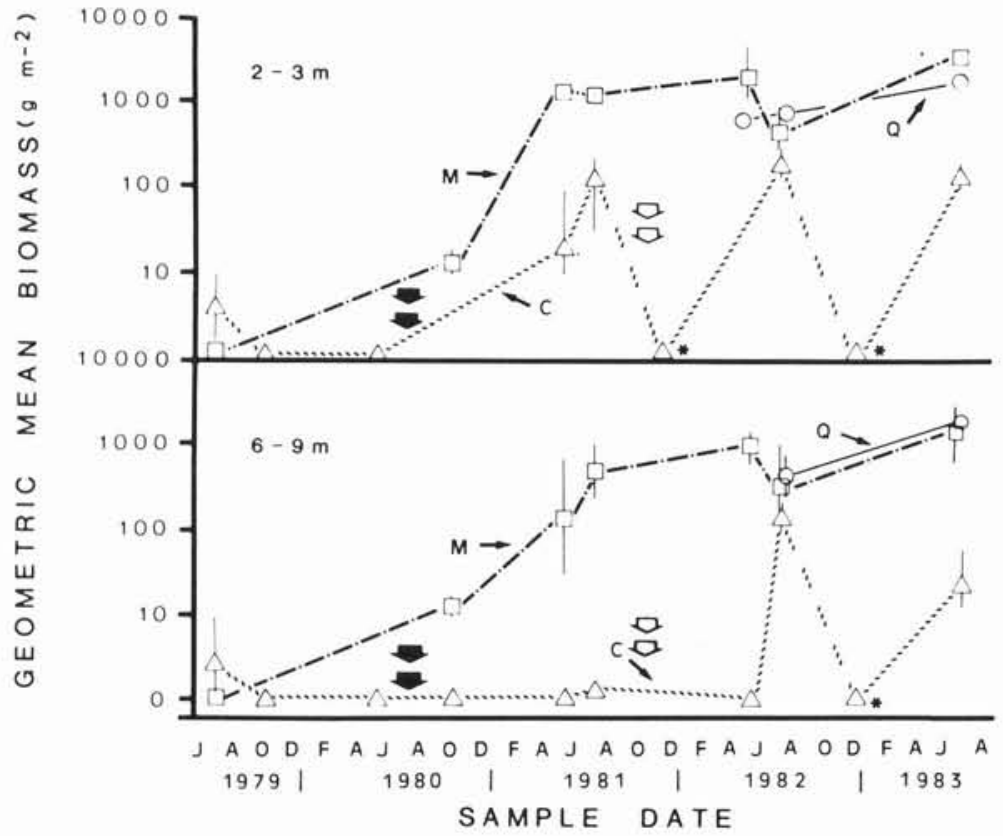

Fig. 2. Total fleshy macroalgal biomass for each transect, depth, and sample date [geometric mean $\left(\mathrm{g} \mathrm{m}^{-2}\right) \pm \mathrm{SE}$ ]. Filled arrows indicate time of urchin removal from the manual removal transect, and open arrows time of first quicklime application. (M: manual removal transect; C: unmanipulated transect; Q: quicklimed transect). Asterisks indicate a decrease in biomass during the autumn, based on the fact that no algae were observed at that time, rather than on quantitative samples 
Fig. 3. Effect of urchin removal on canopy species at 2 to $3 \mathrm{~m}$ (geometric means \pm 1 $\mathrm{SE}$; note $\log _{10}$ scale). M: manual removal transect; C: unmanipulated transect; Q: quicklimed transect. AE: Alaria esculenta, CF: Chordaria flagelliformis, DS: Desmarestia spp.; LD: Laminaria digitata

Fig. 4. Effect of urchin removal on canopy species at 6 to $9 \mathrm{~m}$ (geometric means \pm 1 $\mathrm{SE}$; note $\log _{10}$ scale). $\mathrm{M}$ : manual removal transect; C: unmanipulated transect; $Q$ : quicklimed transect. AC: Agarum cribrosum, AE: Alaria esculenta, CF: Chordaria flagelliformis, DS: Desmarestia spp., LD: Laminaria digitata
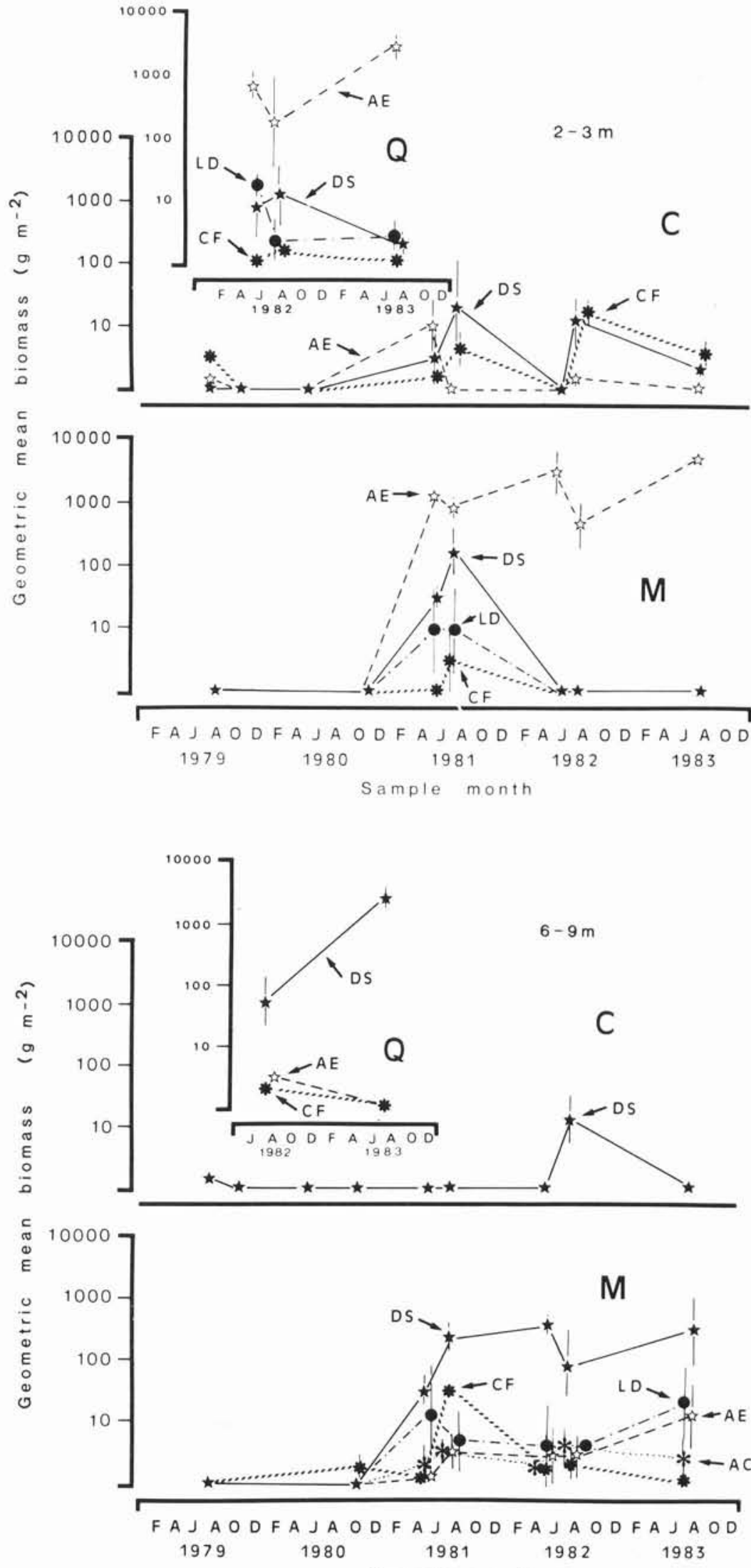


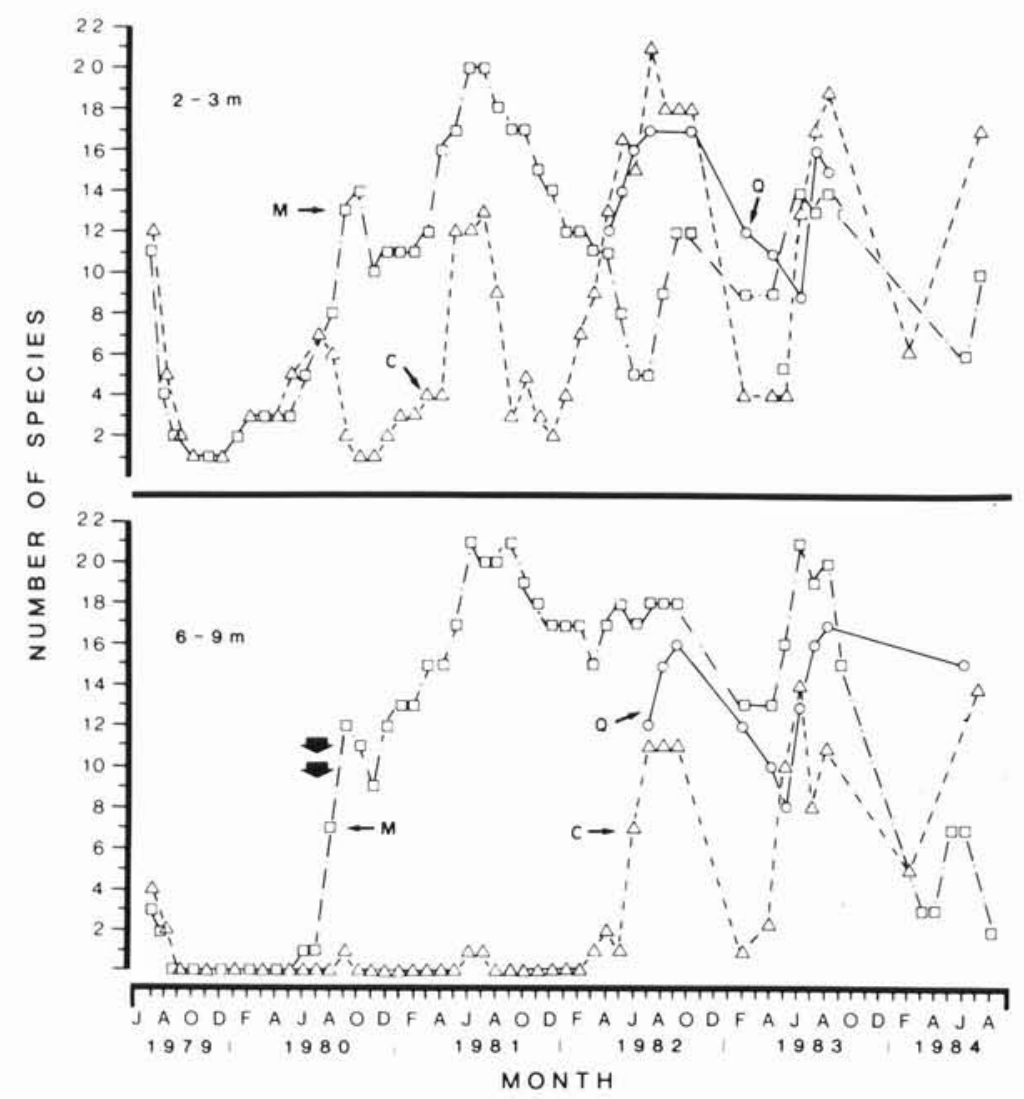

On both of the removal transects Alaria esculenta formed a dense canopy from late winter until early summer. Light readings (taken June 7, 1982 using a Seikonic ${ }^{\circledR}$ photographic light meter) indicated that $<1 \%$ of the light incident at the canopy surface reached the substrate. In late summer and early autumn the canopy opened considerably, when the A. esculenta blades were eroded, and observations of open substrate indicate that much more light penetrated to the substrate.

The biomass of canopy-forming species was always low at 2 to $3 \mathrm{~m}$ on the unmanipulated transect (Fig. 3); only a few scattered Alaria esculenta, Chordaria flagelliformis, and Desmarestia spp. plants were present.

At 6 to $9 \mathrm{~m}$, Desmarestia spp. had the greatest biomass (>95\% the perennial $D$. aculeata) after urchin removal (Fig. 4). Small amounts of Agarum cribrosum, Alaria esculenta and Laminaria digitata were also present on both of the urchin removal transects. One large, fertile sporophyte of Laminaria longicruris was observed at $9 \mathrm{~m}$, and 2 sporophytes at $4 \mathrm{~m}$ on the quicklimed transect during summer 1984, suggesting that they had appeared during the previous winter.

Desmarestia spp. (mainly the annual $D$. viridis) were the only canopy-forming algae present at 6 to $9 \mathrm{~m}$ on the unmanipulated transect, and only in measurable quantity during summer 1982.
Fig. 5. Number of species of fleshy macroalgae vs observation date for each depth and transect. Double arrows indicate time of urchin removal from the manual removal transect

\section{Non-canopy species}

These data are not presented graphically, as there were many species and few clear trends. The biomass of non-canopy species was low throughout the study on both urchin removal transects except during summer 1981. In contrast, several species, especially Eudesme virescens and Ectocarpus siliculosus, increased in biomass on the unmanipulated transect during summers 1982 and 1983.

\section{Species richness}

At 2 to $3 \mathrm{~m}$ on the unmanipulated transect a peak in species richness occurred during spring and summer (May to August) (Fig. 5). During these increases, species richness was also higher on the unmanipulated transect than on the urchin removal transects.

At 6 to $9 \mathrm{~m}$ there were very few detectable species of macroalgae on the unmanipulated transect until spring and summer 1982. A peak in species richness lasted at least until September of that year, but had decreased to a single species (Desmarestia aculeata) by February 1983. Similar increases in species richness occurred on the unmanipulated transect during summers 1983 and 1984 (Fig. 5). 
Differences between unmanipulated and manual removal transects became apparent during the later stages of urchin removal (August 1980); the number of species on the manual removal transect increased, while decreasing ( 2 to $3 \mathrm{~m}$ ) or remaining low (6 to $9 \mathrm{~m}$ ) on the unmanipulated transect. Until June 1981, species richness on the manual removal transect showed an increasing trend, but from August 1981 to June 1982 there was a steady decline in the number of species at 2 to $3 \mathrm{~m}$. In 1982, 1983, and 1984 species richness increased during late summer and early autumn, when the Alaria esculenta blades became eroded (Fig. 5). During late winter and spring the number of species declined again as the $A$. esculenta canopy became closed, reducing the amount of light reaching the understorey. A similar summer-autumn peak in species richness also occurred on the quicklimed transect (Fig. 5).

At 6 to $9 \mathrm{~m}$ (Fig. 5) the divergence in species richness between the unmanipulated and manual removal transects also began during the later stages of urchin removal (August 1980). The removal transects had the greater number of species throughout the study, although the difference between removal and unmanipulated transects was less during summers 1982 and 1983. Species richness decreased considerably on the manual removal transect following the cessation of urchin removal, such that at 6 to $9 \mathrm{~m}$ during summer 1984 there were more species on the quicklimed and unmanipulated transects.

\section{Species diversity}

At 2 to $3 \mathrm{~m}$ on both of the urchin removal transects diversity was greatest 2 mo after urchin removal, and then decreased with time, as dominance by Alaria esculenta increased and its canopy became closed (Fig. 6). Diversity was generally greater on the unmanipulated transect than on the urchin removal transects (Figs. 6 \& 7). Exceptions were those periods during which essentially no macroalgae were present on the unmanipulated transect (autumn 1979; autumn 1980; and spring 1982) (Fig. 7).
The tendency towards strong domination by a single species was less pronounced at 6 to $9 \mathrm{~m}$ than at 2 to $3 \mathrm{~m}$ on the urchin removal transects (Figs. 6 \& 8). At 6 to 9 $\mathrm{m}$, most biomass after the spring of 1981 was Desmarestia aculeata, but on the manual removal transect there were more species of intermediate relative abundance than there were at shallower depths following urchin removal (Fig. 8). Diversity (Fig. 9) was generally low at 6 to $9 \mathrm{~m}$ without urchin removal, except during summers 1979, 1982 and 1983.

\section{Community destruction by reinvading urchins}

Large numbers of urchins began to invade the manual removal area during autumn 1983, where they formed dense aggregations around the dominant algae. By April of 1984 urchins had removed all fleshy macroalgae except for Agarum cribrosum and Ptilota serrata. As of September 1984 these plants showed no detectable sign that they were incurring mortality as a result of grazer damage, and most of the dense aggregations of urchins had dispersed from the area. During autumn 1985 a few of the A. cribrosum plants were still present. This process was repeated on the quicklimed transect, but because of the greater size of the quicklimed area it took one more year for urchins to completely eliminate all algae other than $A$. cribrosum and P. serrata.

\section{Urchin removal}

The percentage removal of urchins was greater at 2 to $3 \mathrm{~m}$ than at 6 to $9 \mathrm{~m}$ where urchin biomass was initially lower (Table 2). Most of the urchins which remained were small $(<1 \mathrm{~cm}$; see Keats et al. 1985b, where this has been discussed).

\section{DISCUSSION}

\section{Effects of urchin removal in Conception Bay}

The rapid development of a dense stand of Alaria esculenta at 2 to $3 \mathrm{~m}$ following urchin removal repre-

Table 2. Estimates of the percentage urchin biomass removed from the urchin removal transects (95\% confidence limits are included - see text for means of calculation)

\begin{tabular}{|c|c|c|c|c|c|}
\hline \multirow{2}{*}{$\begin{array}{l}\text { Depth } \\
\text { range } \\
(\mathrm{m})\end{array}$} & \multirow{2}{*}{$\begin{array}{l}\text { Unmanipulated transect } \\
\text { Geometric } \\
\text { mean biomass } \\
\left(\mathrm{g} \mathrm{m}^{-2}\right)\end{array}$} & \multicolumn{2}{|c|}{ Manual removal transect } & \multicolumn{2}{|c|}{ Quicklimed transect } \\
\hline & & $\begin{array}{l}\text { Geometric } \\
\text { mean biomass } \\
\left(\mathrm{g} \mathrm{m}^{-2}\right)\end{array}$ & $\begin{array}{l}\text { Estimated } \\
\text { percentage } \\
\text { removed }\end{array}$ & $\begin{array}{c}\text { Geometric } \\
\text { mean biomass } \\
\left(\mathrm{g} \mathrm{m}^{-2}\right)\end{array}$ & $\begin{array}{l}\text { Estimated } \\
\text { percentage } \\
\text { removed }\end{array}$ \\
\hline $2-3$ & (457) $635.9(884)$ & (36) $62.0(102)$ & (78) 90.4 (96) & (15) $32.2 \quad$ (71) & (85) 94.9 (98) \\
\hline $6-9$ & (121) 189.5 (297) & (15) 25.1 (41) & (66) 86.6 (95) & (15) $44.9(128)$ & $(-6) 76.3(95)$ \\
\hline
\end{tabular}




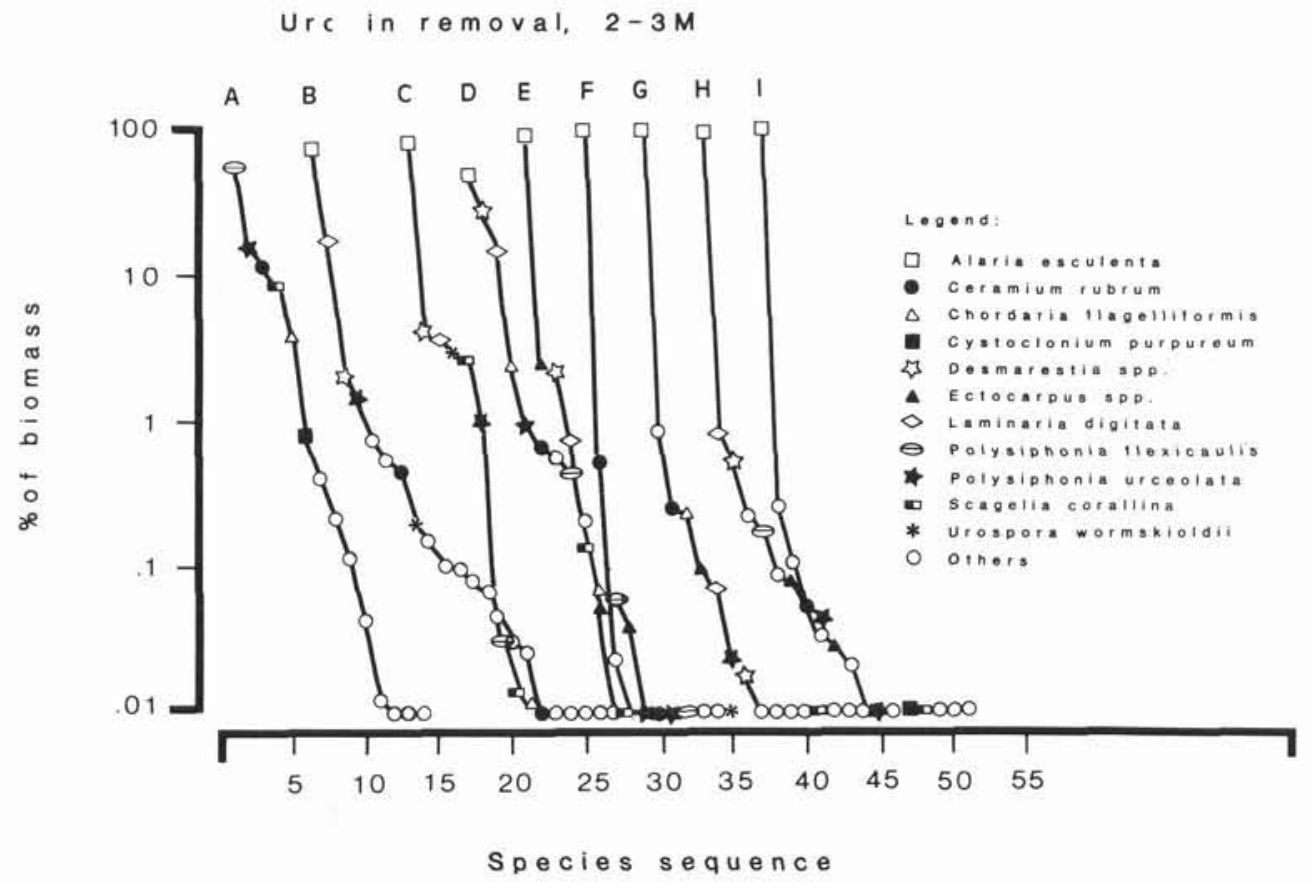

Fig. 6. Species relative abundance curves for sample sets from 2 to $3 \mathrm{~m}$, on the manual removal and quicklimed transects after urchin removal. A: autumn 1980, manual removal transect; B; spring 1981, manual removal transect; C: spring 1982, quicklimed transect; D: summer 1981, manual removal transect; E: summer 1982, quicklimed transect; F: spring 1982, manual removal transect; G: summer 1982, manual removal transect; H: summer 1983, quicklimed transect; I: spring 1983, manual removal transect. Note: Curves representing the quicklimed transect samples are included immediately after those representing samples from the manual removal transect which are approximately equivalent in terms of time since urchin removal

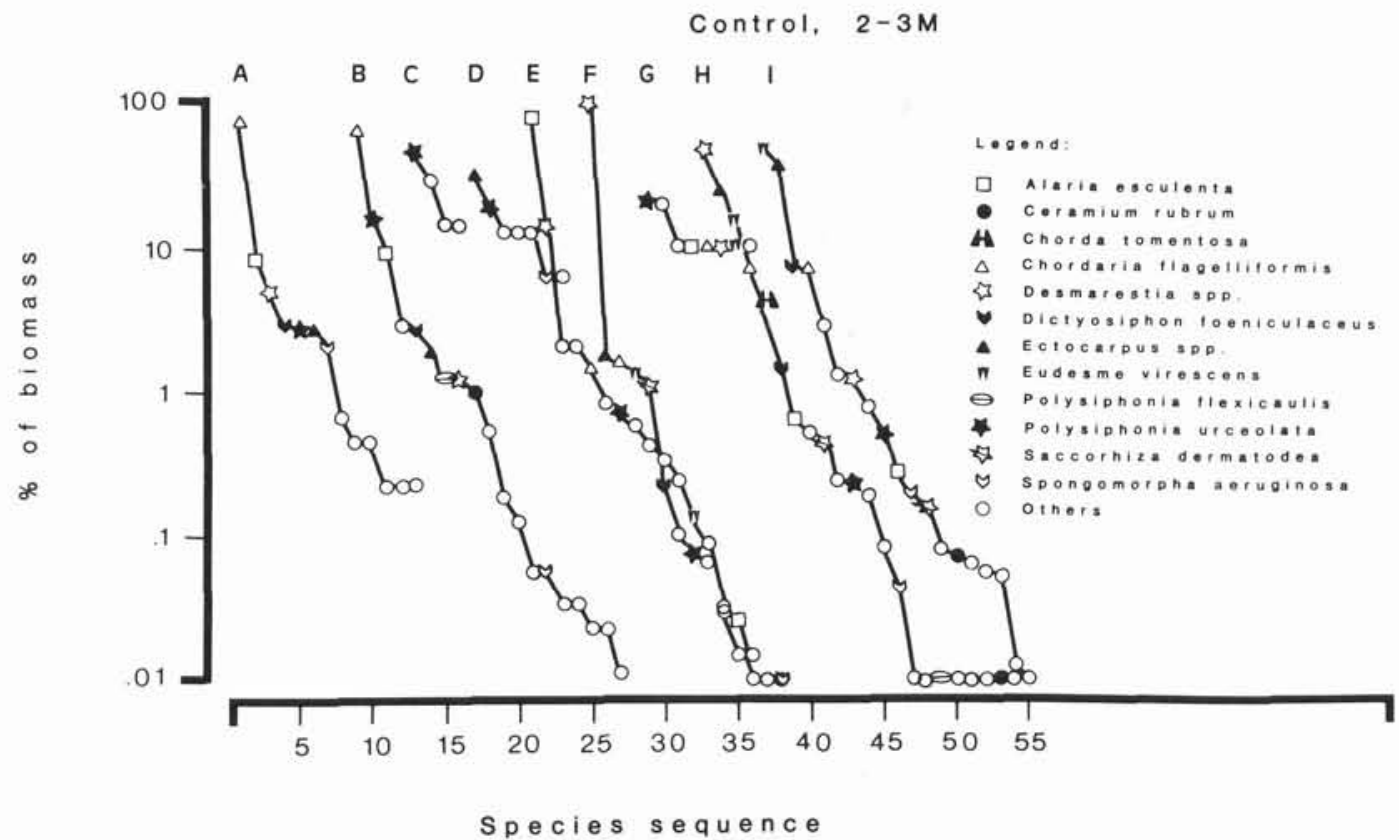

Fig. 7. Species relative abundance curves for sample sets from 2 to $3 \mathrm{~m}$, under unmanipulated conditions. A: summer 1979, manual removal transect (before urchin removal); B: summer 1979, unmanipulated transect; C: autumn 1979, unmanipulated transect; D: autumn 1980, unmanipulated transect; E: spring 1981, unmanipulated transect; F: summer 1981, unmanipulated transect; G: spring 1982, unmanipulated transect; H: summer 1982, unmanipulated transect; I: summer 1983, unmanipulated transect 


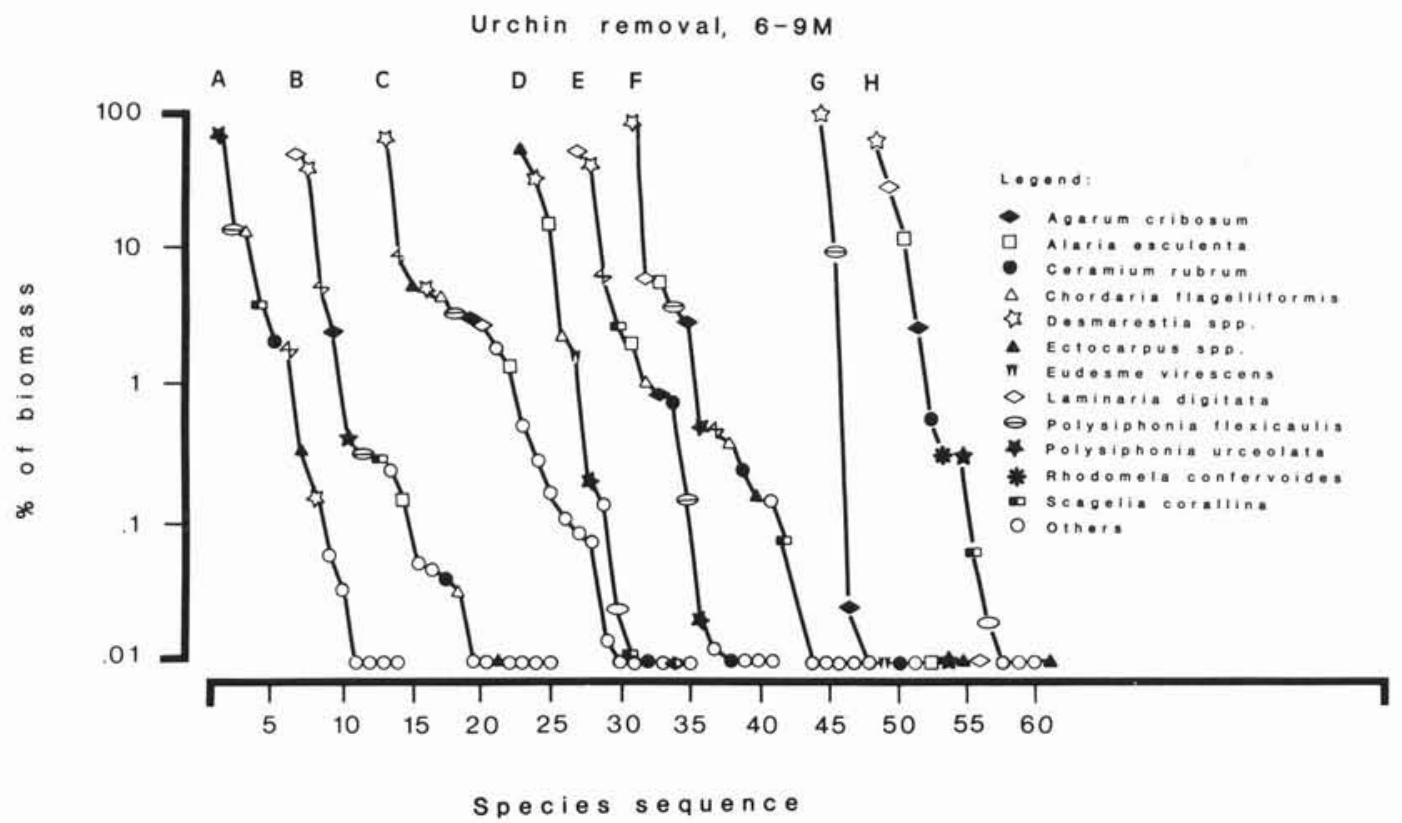

Fig. 8. Species relative abundance curves for sample sets from 6 to $9 \mathrm{~m}$, on the manual removal and quicklimed transects after urchin removal. A: autumn 1980, manual removal transect; B: spring 1981, manual removal transect; C: summer 1981, manual removal transect; D: summer 1982, quicklimed transect; E: spring 1982, manual removal transect; F: summer 1982, manual removal transect, G: summer 1983, quicklimed transect; H: summer 1983, manual removal transect. Note: The curve representing the quicklimed transect samples is included immediately after those representing samples from the manual removal transect which are approximately equivalent in terms of time since urchin removal

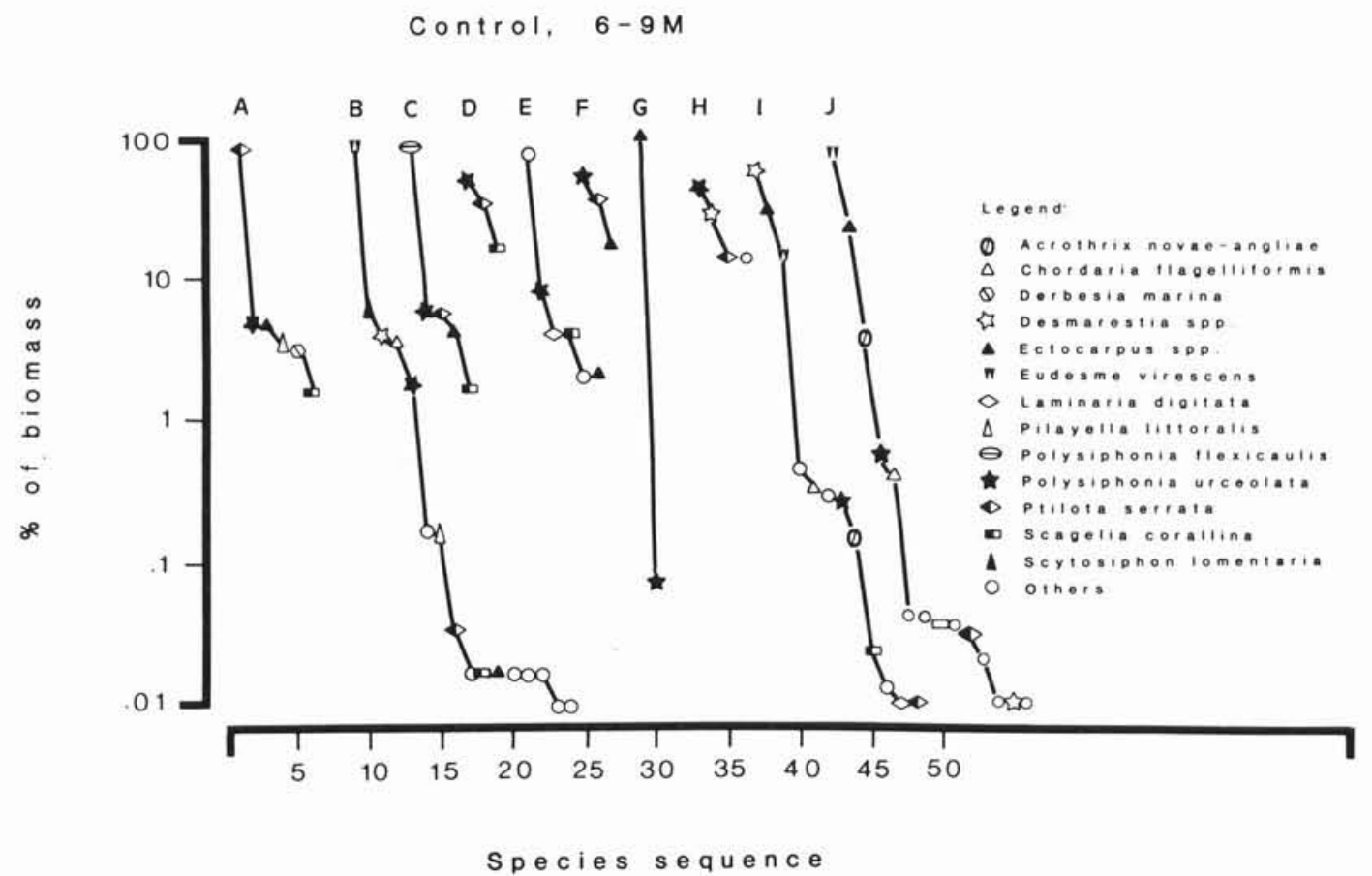

Fig. 9. Species importance curves for sample sets from 6 to $9 \mathrm{~m}$, under unmanipulated conditions. A: summer 1979, manual removal transect (before urchin removal); B: summer 1979, unmanipulated transect; C: autumn 1979, unmanipulated transect; D: spring 1980, unmanipulated transect; E: autumn 1980, unmanipulated transect; F: spring 1981, unmanipulated transect; G: summer 1981, unmanipulated transect; H: spring 1982, unmanipulated transect; I: summer 1982, unmanipulated transect; I: summer 1983, unmanipulated transect 
sents a downward extension of the community dominated by $A$. esculenta, which occurs in the upper subtidal during some years depending on the occurrence and timing of ice-scour (Keats et al. 1985a). A winter reduction in urchin foraging ability by an increase in wave action sometimes leads to a similar downward extension of the A. esculenta community (Himmelman 1985). Such a rapid development was possible because mature A. esculenta sporophytes were abundant in the subtidal fringe (Keats et al. 1985a). These plants must have inundated the substrate with spores, since the substrate became carpeted with sporelings by March. Such high recruitment ensured that there was little space or light for germlings of competitors. The fast growing $A$. esculenta sporophytes rapidly overgrew other species, and within 4 to 5 wk the canopy was closed.

A pattern of an initial increase in species richness and diversity, followed by a decrease as one or a few species dominate the biomass, is commonly observed when urchins have been removed from sea urchin dominated communities (Paine \& Vadas 1969, Foster 1975, Breen \& Mann 1976, Foreman 1977, Pearse \& Hines 1979, Duggins 1980). This was the case in the present study, although it was less pronounced at 6 to $9 \mathrm{~m}$.

Such a pattern may occur because canopy-forming species limit the amount of light reaching the understorey, and therefore monopolize the light resource (Pearse \& Hines 1979, Harkin 1981, Reed \& Foster 1984). The Alaria esculenta canopy eliminated almost all light from the understorey, which probably reduced species diversity during the later stages after urchin removal at 2 to $3 \mathrm{~m}$. A seasonal increase in species richness within the $A$. esculenta community, following the erosion of the $A$. esculenta blades, was superimposed on this overall trend of reduced diversity and richness after canopy closure. This seasonal growth reduction and blade erosion may be a response to high water temperature (Munda \& Lüning 1977) combined with decreased nutrient levels (Buggeln 1974). Renewed growth of A. esculenta in the winter, correlated with decreasing water temperature and increasing nutrients (Buggeln 1974), again produced a closed canopy and reduced the light reaching the understorey. This reduction in light was probably responsible for the seasonal decrease in species richness.

A reduction in urchin grazing at 6 to $9 \mathrm{~m}$ led to domination by Desmarestia aculeata. Its canopy was not as completely closed as that of Alaria esculenta, and more species coexisted with it. The development of the $D$. aculeata canopy was not as rapid as the development of the A. esculenta canopy. Recruitment by $D$. aculeata occurred in the period from late autumn to spring, but a dense carpet of sporelings was never present. D. aculeata was not as abundant in the study area prior to urchin removal, so the availability of spores was probably less than it was for A. esculenta. Recruitment by other canopy-forming species (e.g. A. esculenta, Agarum cribrosum, Desmarestia viridis and Laminaria digitata), and understorey species (e.g. Ceramium rubrum, Polysiphonia urceolata, Rhodomela confervoides, and Scagelia pylaisaei) occurred within the same period as $D$. aculeata recruitment. Once these species attained a large size they continued to coexist with $D$. aculeata. In addition, a number of species (e.g. C. rubrum, Polysiphonia flexicaulis and Ectocarpus spp.) became established as epiphytes on the profusely branched $D$. aculeata, and these contributed further to a higher species diversity. The presence of those epiphytes shows that the morphology of the structurally dominant species may be an important factor affecting species richness and diversity (cf. Paine \& Vadas 1969).

Extensive Alaria esculenta was restricted to the upper edge of the formerly urchin-grazed zone, and only a few sporophytes appeared in the lower part of the urchin removal plots. Competition from other algae was not a significant factor limiting the initial depth penetration of $A$. esculenta because there was welllighted substrate (clean corallines) available at 6 to $9 \mathrm{~m}$ when $A$. esculenta recruitment occurred at 2 to $3 \mathrm{~m}$. Possible reasons for the failure of $A$. esculenta to become dominant at 6 to $9 \mathrm{~m}$ include limited vertical dispersal, poor growth of gametophytes or young sporophytes, or poor fertility of gametophytes at that depth. Further studies would be necessary to determine which (if any) is the correct reason.

The upper limit of abundant Desmarestia aculeata in the urchin removal areas was probably set by the rapid closure of the Alaria esculenta canopy. The presence of D. aculeata at 2 to $3 \mathrm{~m}$ during the first year after urchin removal, and on the unmanipulated transect throughout the study, supports this suggestion, and shows that D. aculeata was not restricted to the lower portion of the removal area by physical factors.

The Alaria esculenta and Desmarestia aculeata communities occurred on both of the urchin removal transects, despite differences in the time and method of urchin removal, suggesting that these associations would probably develop on a larger scale if a mass urchin mortality were to occur. The A. esculenta community was more limited in vertical extent than the $D$. aculeata community, so the latter species comprised most of the algal biomass at the removal sites. Desmarestia spp. dominated beds (including the annual species $D$. viridis) exist at several other sites in Conception Bay. Our observations of very few urchins at these sites (for unknown reasons) suggest that urchin grazing pressure was reduced in comparison with graz- 
ing pressure on the unmanipulated transect. Some of those Desmarestia spp. beds have persisted for at least $8 \mathrm{yr}$ (Keats pers. obs.). Some workers have suggested that the acid content of Desmarestia spp. may confer protection from grazing (Himmelman \& Nedelec 1990), but we have found that in Newfoundland Strongylocentrotus droebachiensis readily consumes both $D$. aculeata and $D$. viridis (Keats et al. 1984, this study). It therefore seems unlikely that acid content plays a role in the persistence of these beds of Desmarestia spp.

\section{Survival of Agarum cribosum and Ptilota serrata after reinvasion by urchins}

The survival of adult Agarum cribrosum for $2 \mathrm{yr}$ after the reinvasion of urchins into the removal area provides a field confirmation of the importance of the species' defense against urchin grazing, possibly due to its high phenolic content (Vadas 1977, Himmelman 1980, Larson et al. 1980, Steinberg 1980, Keats et al. 1984, Himmelman \& Nedelec 1990). Ptilota serrata, which is also avoided by urchins (Himmelman 1980, Keats et al. 1984, Himmelman \& Nedelec 1990), survived for at least 1 yr after urchins had removed all other algae except for $A$. cribrosum. It was also very abundant in the zone (12 to $18 \mathrm{~m}$ ) where $A$. cribrosum biomass was greatest (Keats et al. 1982).

\section{Algal abundance without urchin removal}

The increase in species richness at 2 to $3 \mathrm{~m}$ on the unmanipulated transect during the summer could be due to one or more of a number of factors; a seasonal cycle in urchin behavior (Bernstein et al. 1981), reduced feeding as the urchins' tests become full of gonad material (Kuznetzov 1946, Keats et al. 1984, Himmelman 1985), wave action, or more favorable light or nutrient conditions. Since 1977 one of us (D.K.) has made extensive observations throughout Newfoundland and it is evident that a macroalgal increase, such as occurred within the middle of the urchindominated zone during 1982 and 1983, often occurs in summer at many urchin-dominated sites. A much longer time-series of data, along with measurements of environmental factors and urchin behavior, will be necessary to explain fully this variability in macroalgal biomass within the urchin dominated zone.

The summer annuals, which led to the summer increase in diversity on the unmanipulated transect, were excluded or reduced in abundance at 2 to $3 \mathrm{~m}$ on the experimental transects by Alaria esculenta, and at 6 to $9 \mathrm{~m}$ by Desmarestia aculeata. Sea urchin grazing may therefore increase the overall diversity of the community by preventing domination by $A$. esculenta along the upper edge of the urchin-dominated zone, and by $D$. aculeata in deeper water. Similar increases in overall community diversity in the presence of heavy grazing has been reported in other areas (Vance 1979, Choat \& Schiel 1982).

\section{Comparison with other urchin removal studies in the Northwest Atlantic}

A major difference among areas in the Northwest Atlantic, in the response of the algal community to urchin removal from urchin-dominated areas, is the abundance of Laminaria longicruris in the post urchin removal community. In Nova Scotia L. longicruris colonized rapidly, and became the dominant species within a year (Breen \& Mann 1976, Chapman 1981, Johnson 1984, Miller 1985, Johnson \& Mann 1988). In the present study area that species did not appear for $2 \frac{1}{2}$ yr after urchin removal, and then only 3 sporophytes were found at the quicklimed site. On the north shore of the lower St. Lawrence Estuary a few L. longicruris sporophytes appeared during the first 1 to 3 mo after urchin removal (Himmelman et al. 1983). Those plants attained a large size, but there was little or no further recruitment.

This difference is probably related to the availability of a spore source adjacent to the removal sites, as Chapman (1981) and Johnson \& Mann (1988) have demonstrated that the time taken for a Laminaria bed to develop depends on the distance from a refugial population capable of providing spores. A similar relationship has been shown for Macrocystis pyrifera (Anderson \& North 1966), although recent studies suggest that dispersal may be much better during storms (Reed et al. 1988).

Extensive Laminaria longicruris beds exist in Newfoundland, for example in some parts of Placentia Bay (Keats pers. obs.), at the head of Fortune Bay (Keats et al. 1982), and in Bonne Bay (Hooper 1975). Extensive urchin-dominated areas exist on the Gulf of St. Lawrence coast of Newfoundland, between Bonne Bay and the Bay of Islands (Keats pers. obs. 1983-1984). On the open coast outside of Bonne Bay and the Bay of Islands L. longicruris sporophytes are commonly encountered in the subtidal fringe, and as isolated patches on boulder and ridge tops, habitats from which the species is absent on the east coast. It seems likely that algal beds dominated by $L$. longicruris would develop in that part of the Gulf of St. Lawrence, and on the south coast of Newfoundland, in the event of a decrease in urchin grazing.

The response of the algal community to urchin 
removal in the lower St. Lawrence Estuary showed other differences from the response of the algal community in Conception Bay. Although Laminaria digitata, L. longicruris, and Desmarestia spp. occurred after urchin removal, neither extensive Laminaria spp. nor Desmarestia spp. developed in the area studied by Himmelman et al. (1983). Rather, below the zone of greatest Alaria esculenta biomass, there developed a mixture of Agarum cribrosum, A. esculenta, Ulvaria obscura, and Ptilota serrata.

Some of these differences are probably related to the fact that the St. Lawrence Estuary experiences summer water temperatures considerably lower than those generally experienced at the Conception Bay site. In the St. Lawrence estuary Alaria esculenta germlings appeared in July, soon after urchin removal, and attained a large stature by October (Himmelman et al. 1983). A second crop of germlings appeared in February. In Conception Bay A. esculenta germlings did not appear following urchin removal until December, were not abundant until February, but they attained a large stature by April. A. esculenta recruitment is greatest when water temperatures are low in Newfoundland (South \& Hooper 1980), so its extended recruitment period at the Quebec site was probably a result of the lower summer water temperature there. Shortly after urchin removal Ulvaria obscura became abundant throughout the depth range studied by Himmelman et al (1983). It and other ulvoids were essentially absent from the present study area. In Newfoundland $U$. obscura is a winterspring species (South \& Hooper 1980), suggesting a dependence on colder water temperatures.

These differences serve to emphasize the importance of using caution in interpreting detailed local results in a regional or broader geographical context. It is also important to note that most statements made concerning changes in community structure after urchin removal apply only to a relatively short time scale $(4$ to $5 \mathrm{yr}$ ). Given sufficient time it is likely that there would be further changes in community structure, perhaps even the eventual development of a Laminaria-dominated community once a local spore source becomes established.

Acknowledgements. We acknowledge the financial support of NSERC strategic grant G-0233 and NSERC operating grants A-4648 and A-1732, Environment Canada, Department of Fisheries and Oceans, Science Subvention Grant, and the Province of Newfoundland and Labrador, Department of Fisheries to G. R. South and D. H. Steele. The following persons gave technical and diving assistance: Don Chafe, Clyde Collier, Steve Dawson, Suzan Dionne, Ross Downey, Cheryl Gullason, Kathy Knight, Keith Mercer, Sandra O'Neill, Peter Noble, Ian Roy, and Pierre Ryan. Suzan Dionne patiently drafted most of the figures. This paper has also benefitted greatly from discussions with Robert Elner, Larry Harris, John Himmelman, Robert Hooper, Guy Martel, Robert Miller, Doug
Morris, John Pringle, Robert Steneck, Robert Vadas and Alan Whittick. We especially thank Nils Hagen for sharing his thoughts on geographic variation in the ecological role of green sea urchin grazing. D.W.K. wishes to thank the University of the Western Cape for providing computer and technical facilities.

\section{LITERATURE CITED}

Anderson, E. K., North, W. J. (1966). In situ studies of spore production and dispersal in the giant kelp Macrocystis. Proc. Int. Seaweed Symp. 5: 73-86

Bernstein, B. B., Williams, B. E., Mann, K. H. (1981). The role of behavioral responses to predators in modifying urchins' (Strongylocentrotus droebachiensis) destructive grazing and seasonal foraging patterns. Mar. Biol. 63: 39-49

Breen, P. A., Mann, K. H. (1976). Destructive grazing of kelp by sea urchins in eastern Canada. J. Fish. Res. Bd Can. 33: $1278-1283$

Buggeln, R. G. (1974). Physiological investigations on Alaria esculenta (L.) Grev. (Laminariales). I. Elongation of the blade. J. Phycol. 10: 283-288

Chapman, A. R. O. (1981). Stability of sea urchin dominated barren grounds following the destructive grazing of kelp by sea urchins in St. Margaret's Bay, Eastern Canada. Mar. Biol. 62: 307-311

Choat, J. H., Schiel, D. R. (1982). Patterns of distribution and abundance of large brown algae and invertebrate herbivores in subtidal regions of northern New Zealand. J. exp. mar. Biol. Ecol. 60: 129-162

Dayton, P. K. (1975). Experimental evaluation of ecological dominance in a rocky intertidal algal community. Ecol. Monogr. 45: 137-159

Duggins, D. O. (1980). Kelp beds and sea otters - an experimental approach. Ecology 61: 447-453

Foreman, R. E. (1977). Benthic community modification and recovery following intensive grazing by Strongylocentrotus droebachensis. Helgoländer wiss. Meeresunters. 30: 468-484

Foster, M. S. (1975). Algal succession in a Macrocystis pyrifera forest. Mar. Biol. 32: 313-329

Hagen, N. T. (1983). Destructive grazing of kelp beds by sea urchins in Vestfjorden, northern Norway. Sarsia 68: $177-190$

Harkin, E. (1981). Fluctuations in epiphyte biomass following Laminaria hyperborea canopy removal. Proc. Int. Seaweed. Symp.10: 303-308

Harris, L.G. (1981). Studies of community succession in a sea urchin barrens area following sea urchin removal. Am. Zool. 21: 1019

Harrold, C., Pearse, J. S. (1987). The ecological role of echinoderms in kelp forests. Echinoderm Stud. 2: 137-233

Hart, M. W., Scheibling, R. E. (1988). Heat waves, baby booms, and the destruction of kelp beds by sea urchins. Mar. Biol. 99: 167-176

Himmelman, J. H. (1980). The role of the green sea urchin, Strongylocentrotus droebachiensis, in the rocky subtidal region of Newfoundland. Can. Tech. Rep. Fish. Aquat. Sci. 954: 92-119

Himmelman, J. H. (1985). Urchin feeding and macroalgal distribution in Newfoundland, Eastern Canada. Naturaliste can. 111: 337-348.

Himmelman, J. H., Cardinal, A., Bourget, E. (1983). Community development following removal of urchins, Strongylocentrotus droebachiensis, from the subtidal zone of the 
St. Lawrence Estuary, eastern Canada. Oecologia (Berl.) 59: $27-39$

Himmelman, J. H., Nedelec, H. (1990). Urchin foraging and algal survival strategies in intensly grazed communities in eastern Canada. Can. J. Fish. Aquat. Sci. 47: 1011-1026

Hooper, R. G. (1975). Bonne Bay Marine Resources. An ecological and biological assessment. Parks Canada Atlantic Regional Office (Halifax, N.S.) Contract No. ARO74-83, Vol. 1, Vol. 2, Maps (mimeo.)

Hooper, R. G. (1980), Observations on algae-grazer interactions in Newfoundland and Labrador. Can. Tech. Rep. Fish. Aquat. Sci. 954: 92-119

Hooper, R. G., South, G. R., Whittick, A. (1980). Ecological and phenological aspects of the marine phytobenthos of the island of Newfoundland. In: Price, J. H., Irvine, D. E. G., Farnham, W. F. (eds.) The shore environment, Vol. 2: Ecosystems. Academic Press, London, p. 395-423

Johnson, C. R. (1984). Ecology of the kelp Laminaria longicruris and its principal grazers in the rocky subtidal off Nova Scotia. Ph. D. thesis, Dalhousie University, Halifax

Johnson, C. R., Mann, K. H. (1988). Diversity, patterns of adaptation, and stability of Nova Scotian kelp beds. Ecol. Monogr. 58: 129-154

Jones, G. M., Scheibling, R. E., Hebda, A. J., Miller, R. J. (1985). Amoeba in tissues of diseased echinoids (Strongylocentrotus droebachiensis in Nova Scotia. Proc. Int. Echinoderm Conf. 5: 289-293

Jones, N. S., Kain, J. M. (1967). Subtidal algal colonization following the removal of Echinus. Helgoländer wiss. Meeresunters. 15: 460-466

Keats, D. W. (1986). The effects of the experimental removal of green sea urchins, and of ice-scour on sublittoral benthic macro-algal communities in eastern Newfoundland. Ph.D. thesis, Memorial Univ. Nfld., St. John's

Keats, D. W., South, G. R., Steele, D. H. (1982). The occurrence of Agarum cribrosum (Mert.) Bory. (Phaeophyta, Laminariales) in relation to some of its competitors and predators in Newfoundland. Phycologia 21: 189-191

Keats, D. W., South, G. R., Steele, D. H. (1985a). The effect of physical disturbance by pack-ice on algal biomass and diversity in the upper sublittoral of eastern Newfoundland. Mar. Ecol. Prog. Ser. 25: 151-158

Keats, D. W., South, G. R., Steele, D. H. (1985b). The ecology of juvenile green sea urchins (Strongylocentrotus droebachiensis) at an urchin dominated sublittoral site. Proc. Int. Echinoderm Conf. 5: 295-302

Keats, D. W., Steele, D. H., South, G. R. (1984). Depth dependent reproductive output of the green sea urchin (Strongylocentrotus droebachiensis O. F. Mull.) in relation to the nature and availability of food. J. exp. mar. Biol. Ecol. 80: $77-91$

Kuznetzov, V. V. (1946). Nutrition and growth of plant feeding marine invertebrates of the eastern Murman. Izv. Akad. Nauk SSSR, Ser. Biol. 4: 421-452

Larson, B. R., Vadas, R. L., Keser, M. (1980). Feeding and nutritional ecology of the sea urchin Strongylocentrotus drobachiensis in Maine, USA. Mar. Biol. 59: 49-62

Lawrence, J. M. (1975). On the relationships between marine plants and sea urchins. Oceanogr. mar. biol. A. Rev. 13: 213-286

Mann, K. H. (1977). Destruction of kelp beds by sea urchins: a cyclical phenomenon or irreversible degradation. Helgoländer wiss. Meeresunters. 30: 455-467

May, R. M. (1981). Patterns in multi-species communities. In:
May, R. M. (ed.) Theoretical ecology, 2nd edn. Sinauer Associates, Sunderland, p. 197-227

Miller, R. J. (1985). Succession in sea urchin and seaweed abundance in Nova Scotia, Canada. Mar. Biol. 84: 275-286

Moore, D. S., Miller, R. J. (1983). Recovery of macroalgae following widespread sea urchin mortality with a description of the nearshore hard-bottom habitat on the Atlantic coast of Nova Scotia. Can. Tech. Rep. Fish. Aquat. Sci. 1230: $1-94$

Munda, I. M., Lüning, K. (1977). Growth performance of Alaria esculenta off Helgoland. Helgoländer wiss. Meeresunters. 29: 311-314

Paine, R. T., Vadas, R. L. (1969). The effects of grazing by sea urchins, Strongylocentrotus spp., on benthic algal populations. Limnol. Oceanogr. 14: 710-719

Pearse, J. S., Hines, A. H. (1979). Expansion of a central California kelp forest following the mass mortality of sea urchins. Mar. Biol. 51: 83-91

Pringle, J. D. (1986). A review of urchin/macro-alagal associations with a new synthesis for nearshore, eastern Canadian waters. Monografias biol. 4: 191-218

Propp, M. V. (1977). Ecology of the sea urchin Strongylocentrotus droebachiensis of the Barents Sea: metabolism and regulation of abundance. Biol. Morya (Vladivostok) 1: 39-51

Reed, D. C., Foster, M. S. (1984). The effects of canopy shading on algal recruitment and growth in a giant kelp forest. Ecology 65: 937-948

Reed, D. C., Laur, D. R., Ebling, A. W. (1988). Variation in algal dispersal and recruitment: the importance of episodic events. Ecol. Monogr. 58: 321-335

Scheibling, R. E. (1984). Echinoids, epizootics and ecological stability in the rocky subtidal off Nova Scotia, Canada. Helgoländer Meeresunters. 38: 233-242

Scheibling, R. E. (1986). Increased macroalgal abundance following mass mortalities of sea urchins (Strongylocentrotus droebachiensis) along the Atlantic coast of Nova Scotia. Oecologia (Berl.) 68: 186-198

Sokal, R. R., Rohlf, F. J. (1969). Biometry. W. H. Freeman and Co., San Francisco

South, G. R. (1984). A checklist of marine algae of eastern Canada, second revision. Can. J. Bot. 62: 680-704

South, G. R., Hooper, R. G. (1980). A catalogue and atlas of the benthic marine algae of the island of Newfoundland. Mem. Univ. Nfld. Occas. Papers Biol. 3: 1-136

Steinberg, P. D. (1980). The potential role of phenolic compounds as herbivore defenses in brown algae. Am. Zool. 20: 885

Tilman, D. (1982). Resource competition and community structure. Monographs in population biology \# 17, Princeton Univ. Press, Princeton

Vadas, R. L. (1968). The ecology of Agarum and the kelp bed community. Ph. D. thesis, Univ. Washington, Seattle

Vadas, R. L. (1977). Preferential feeding: an optimization strategy in sea urchins. Ecol. Monogr. 47: 337-371

Vance, R. R. (1979). Effects of grazing by the sea urchin, Centrostephanus coronatus, on prey community composition. Ecology 60: 537-546

Whittaker, R. H. (1965). Dominance and diversity in land plant communities. Science 147: 250-260

Wynne, M. J. (1985). Concerning the names Scagelia corallina and Heterosiphonia wurdemannii (Ceramiales, Rhodophyta). Cryptogam.: Algol. 6: 81-90 